\title{
Morphological separation of Tomicus piniperda and T. destruens (Coleoptera: Curculionidae: Scolytinae): new and old characters
}

\author{
MASSIMO FACCOLI \\ Department of Environmental Agronomy and Crop Protection, University of Padua, Viale dell’Università 16/a, 35020 Legnaro (PD), \\ Italy; e-mail: massimo.faccoli@unipd.it
}

Key words. Coleoptera, Curculionidae, Scolytinae, Tomicus, Blastophagus, identification, morphology

\begin{abstract}
Tomicus piniperda and $T$. destruens are sibling species which are extremely difficult to separate by morphological characters. Although several papers report differences between the two species, many characters need confirmation or better description. Moreover, new morphological characters are required for correct species determination. For these purposes, eight populations of $T$. destruens from Italy, Greece, Spain and Algeria, and ten of T. piniperda from Finland, Poland, Czech Republic, Austria, Sweden and Italy, were investigated considering eleven morphological characters. The morphological differences most useful for the species separation include four previously described characters (colour of the elytra, colour of the antennal club, distribution of the antennal setae, distribution of the punctures along the elytral declivity), and four new characters (body proportions, setation of the first antennal club suture, sculpture of the elytral declivity and striae density of the pars stridens). Distribution of the two species is discussed and an illustrated key is included.
\end{abstract}

\section{INTRODUCTION}

The species of the genus Tomicus Latreille, 1802 (= Blastophagus Eichhoff, 1864; = Myelophilus Eichhoff, 1878) belong to the most dangerous pine pests in Eurasia, playing a major role in the decline of many pine forests (Eichhoff, 1881; Escherich, 1923; Postner, 1974; Långström \& Hellqvist, 1991; Ye, 1991; Ye \& Lieutier, 1997; Dajoz, 2000). Of the six Tomicus species known to the world (Wood \& Bright, 1992), only $T$. piniperda (Linnaeus, 1758), $T$. destruens (Wollaston, 1865) and $T$. minor (Hartig, 1834) occur in Europe (Pfeffer, 1995). Tomicus piniperda is widespread in Eurasia and it has recently been introduced to North America (Haack \& Kucera, 1993; Haack \& Poland, 2001; Haack et al., 2000). Tomicus destruens is found in all circumMediterranean regions and Madeira Islands, whereas Tomicus minor occurs in Europe and Asia (Pfeffer, 1995).

For a long time, $T$. piniperda and $T$. destruens have been considered as synonymous (Schedl, 1932, 1946), rejecting the conclusions of Wollaston (1865), who described $T$. destruens as a separate species based on specimens collected in Madeira. Wollaston (1865) described $T$. destruens as "different from $T$. piniperda in being on the average a little larger and thicker, and its elytra, which are more coarsely rugulose, being always more or less ferruginous. Its antennae are totally pale (brown in T. piniperda) with their clubs somewhat longer and more acute". Reitter (1913), apparently unaware of Wollaston's paper and finding differences in the elytra colour, reported $T$. piniperda var. rubripennis (elytra reddish) as a Mediterranean variety of $T$. piniperda (elytra brown). The same character was also used by Krausse (1920), who described T. piniperda var. rubescens as having reddish elytra. Later, Russo (1940) studied both morphology and biology of some populations of $T$. piniperda var. rubripennis Reitter occurring in central Italy, without adding new characters. However, these varieties have no taxonomical value as they were described only on the basis of different colours, and not supported by morphological or genetic differences. Not until 1971 did Lekander, who was looking for new morphological characters of the larvae, accept $T$. destruens as a different species having three pairs of epipharyngeal setae instead of the four pairs found in T. piniperda. Lekander (1971) briefly commented also on the size and proportions of the two species, but did not provide measurements or other numerical data. Kerdelhué et al. (2002) described the declivity of $T$. piniperda elytra with one row of small and deep punctures occurring between the main punctures of the second interstria, whereas two to three rows can be observed in $T$. destruens. Kohlmayr et al. (2002) reported that three rows of setae occur on the antennal club of $T$. destruens between the second and third suture, whereas $T$. piniperda has only one row of setae. In addition, on the elytra of $T$. destruens the same authors found types of setae not occurring on the elytra of T. piniperda. The descriptions of Wollaston and Lekander were recently supported by genetic analyses, which confirm that $T$. destruens and $T$. piniperda are two different species (Gallego \& Galian, 2001; Kerdelhuè et al., 2002; Kohlmayr et al., 2002; Faccoli et al., 2005).

However, despite the morphological characters reported in the literature, separation of the two Tomicus species is still extremely difficult. No illustrated key is available, and the differences described in the literature very often include unstable characters such as elytral or antennal colour, which can change with insect age. As a result of the uncertain identification of the species, most scientific papers published in Mediterranean countries, where $T$. destruens is more common, report $T$. piniperda as the investigated species (Eggers, 1929; Schedl, 1932; Russo, 


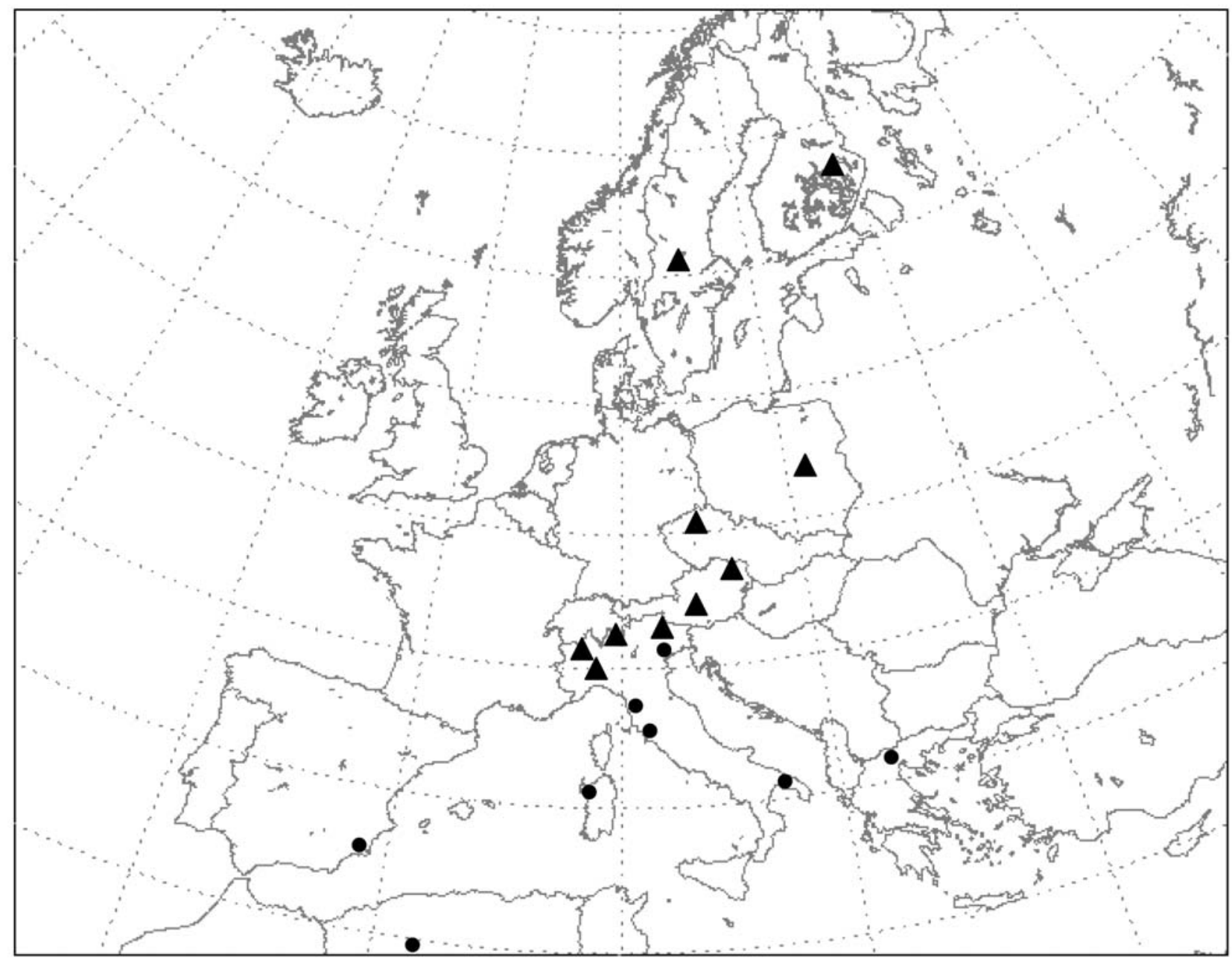

Fig. 1. Tomicus populations sampled in the present study. Dots: T. destruens; Triangles: T. piniperda. Information about the sampled populations is given in Tables 1 and 2 .

1940, 1946; Balachowsky, 1949; Chararas, 1962; Masutti, 1969; Carle, 1975; Triggiani, 1983, 1984; Gil \& Pajeras, 1986; Ferreira \& Ferreira, 1986). In the scientific literature these two Tomicus species have been often confused, which results in mixing of data from biological and control studies. From this point of view, correct identification of the species remains one of the main problems for Tomicus investigations carried out in southern Europe.

The aims of the present paper were to investigate the validity of the morphological characters reported in the literature (Reitter, 1913; Krausse 1920; Pfeffer, 1995; Kerdelhué et al., 2002; Kohlmayr et al., 2002), and to look for new characters useful for Tomicus species identification.

\section{MATERIAL AND METHODS}

\section{Insect collection}

Callow and mature adults of $T$. destruens and $T$. piniperda were collected in eighteen localities from Europe and North Africa for a total of 230 specimens (Fig. 1, Tables 1 and 2). The

TABle 1. Analysed populations of Tomicus destruens. Host: P.p. - Pinus pinaster; P.d. - P. pinea; P.h. - P. halepensis. * Populations investigated by Kohlmayr et al. (2002). Countries are reported using the international abbreviation code.

\begin{tabular}{cccccccccc}
\hline Population & N of callows & N of matures & Country & Region/Locality/City & Lat. N & Long. E & M a.s.l. & Host & Collected by \\
\hline 1 & - & 19 & I & Valle Vecchia & $45^{\circ} 54^{\prime}$ & $12^{\circ} 36^{\prime}$ & 4 & P.p. & M. Faccoli \\
2 & - & 19 & I & Poggio, Valicaia & $43^{\circ} 34^{\prime}$ & $11^{\circ} 13^{\prime}$ & 47 & P.p. & R. Tiberi \\
3 & 20 & - & I & Alberese & $42^{\circ} 40^{\prime}$ & $11^{\circ} 06^{\prime}$ & 300 & P.d. & A. Battisti \\
4 & - & 20 & I & Ginosa & $40^{\circ} 34^{\prime}$ & $16^{\circ} 45^{\prime}$ & 3 & P.h. & O. Triggiani \\
5 & - & 6 & I & Platamona & $40^{\circ} 43^{\prime}$ & $8^{\circ} 34^{\prime}$ & 27 & P.d. & M. Faccoli \\
6 & 2 & 3 & E & Murcia* & $37^{\circ} 58^{\prime}$ & $1^{\circ} 07^{\prime}$ & 50 & P.h. & J. Galian \\
7 & 2 & 3 & G & Thessaloniki* & $40^{\circ} 39^{\prime}$ & $22^{\circ} 38^{\prime}$ & 300 & $?$ & N.D. Avtzis \\
8 & - & 20 & AL & Oselfa & $34^{\circ} 40^{\prime}$ & $3^{\circ} 14^{\prime}$ & $?$ & P.h. & G. Chakali \\
\hline
\end{tabular}


TABle 2. Analysed populations of Tomicus piniperda. Host: P.s. - P. sylvestris; P.n. - P. nigra. * Populations investigated by Kohlmayr et al. (2002). Countries are reported using the international abbreviation code.

\begin{tabular}{cccccccccc}
\hline Population & N of callows & N of matures & Country & Region/Locality/City & Lat. N & Long. E & M a.s.l. & Host & Collected by \\
\hline 1 & - & 3 & FIN & Joensuu* & $62^{\circ} 36^{\prime}$ & $29^{\circ} 46^{\prime}$ & 100 & P.s. & M. Robbo \\
2 & - & 6 & PL & Sekocin* & $52^{\circ} 06^{\prime}$ & $20^{\circ} 52^{\prime}$ & 100 & P.s. & J. Hilszczanski \\
3 & 4 & 1 & CZ & Stará Boleslav* & $50^{\circ} 12^{\prime}$ & $14^{\circ} 44^{\prime}$ & 250 & P.s. & M. Knížek \\
4 & 8 & - & A & Kühnsdorf* & $46^{\circ} 37^{\prime}$ & $14^{\circ} 36^{\prime}$ & 440 & P.s. & C. Stauffer \\
5 & 5 & - & A & Mattesburg & $47^{\circ} 44^{\prime}$ & $16^{\circ} 24^{\prime}$ & 280 & P.s. & C. Stauffer \\
6 & 20 & - & I & Villasantina & $46^{\circ} 25^{\prime}$ & $12^{\circ} 55^{\prime}$ & 363 & P.s. & F. Stergulc \\
7 & - & 19 & I & Sonico & $46^{\circ} 11^{\prime}$ & $10^{\circ} 23^{\prime}$ & 1.010 & P.s. & A. Ducoli \\
8 & 20 & - & I & Rocciamelone & $45^{\circ} 10^{\prime}$ & $7^{\circ} 80^{\prime}$ & 1.600 & P.s. & I. Currado \\
9 & - & 20 & I & Passo del Bocco & $42^{\circ} 38^{\prime}$ & $11^{\circ} 05^{\prime}$ & 1.100 & P.n. & A. Battisti \\
10 & - & 10 & S & Fredriksberg & $60^{\circ} 08^{\prime}$ & $14^{\circ} 22^{\prime}$ & 40 & P.s. & M. Faccoli \\
\hline
\end{tabular}

insects were collected from pine shoots found in the litter (mature adults), sampled from pine stems at the beginning of the bark colonisation (mature adults), and from breeding cages containing infested pine logs (callow adults). Some of the populations sampled from central and north Europe were the same as those investigated by Kohlmayr et al. (2002) for genetic purposes (Tables 1 and 2).

\section{Morphological investigations}

Six characters reported in the literature and four new morphological characters were tested for separation of $T$. piniperda and T. destruens. In particular, according to the specimen availability (Tables 1 and 2), the following characters were investigated:

\section{(1) Colour of elytra}

The character was investigated for 149 mature adults, 90 of $T$. destruens and 59 of T. piniperda (Tables 1 and 2). Many authors have reported differences in elytral colour between these Tomicus species (Reitter, 1913; Krausse 1920; Pfeffer, 1995). However, as is difficult to describe a colour or its intensity in different specimens, in the present paper we investigated if the elytra are similar in colour or lighter than the pronotum, which is always black in mature adults.

\section{(2) Colour of antennal club}

The colour of the antennal club, yellow in T. destruens and brown in T. piniperda (Wollaston, 1865; Pfeffer, 1995), was

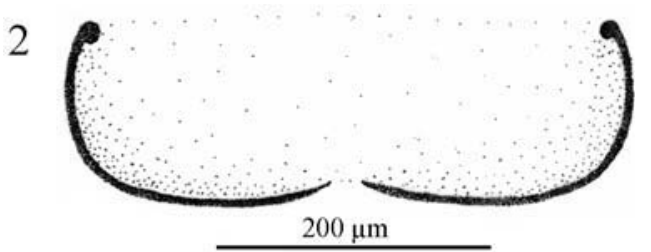

3

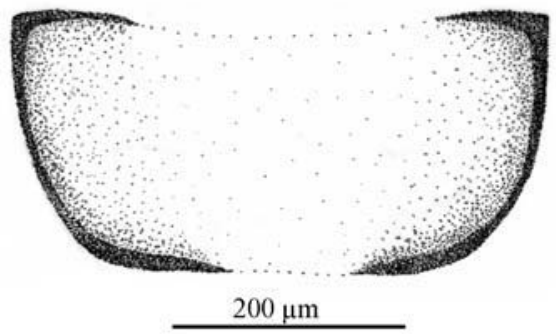

Figs 2-3: Eighth sternite of Tomicus destruens. 2 - male; 3 female. tested in $90 \mathrm{~T}$. destruens and $59 \mathrm{~T}$. piniperda, comprising both callow (81) and mature specimens (149) (Tables 1 and 2).

\section{(3) Setation of antennal club}

Kohlmayr et al. (2002) suggested separating the two Tomicus species by the density of setae occurring on the surface of the third segment of the antennal club, where $T$. piniperda has only a few setae and $T$. destruens many more. The character was investigated for $98 \mathrm{~T}$. destruens and $84 \mathrm{~T}$. piniperda, considering both callow and mature adults.

(4) Type and distribution of setae along the elytral interstriae

Kohlmayr et al. (2002) reported three different types of setae (A, B and C) occurring on the elytra of $T$. piniperda and $T$. destruens. The setae A and B were found on both the species, whereas the setae of type $\mathrm{C}$ were only found in $T$. destruens. To investigate this character, 298 elytra of mature adults $(90 \mathrm{~T}$. destruens and $59 T$. piniperda) were analysed by stereoscope and S.E.M.

\section{(5) Distribution of punctures along the declivity}

According to Kerdelhué et al. (2002), the declivity of $T$. piniperda has one row of more-or-less regularly spaced, small, deep punctures occurring between the main punctures of the second interstriae, whereas $T$. destruens has scattered fine punctures occurring in two or three rows. This character has been investigated in $116 \mathrm{~T}$. piniperda and $114 \mathrm{~T}$. destruens, considering both callow and mature adults (Tables 1 and 2).

(6) Sculpture of elytral declivity

In the original description of $T$. destruens, Wollaston (1865) described the elytral declivity as being duller and more wrinkled than in $T$. piniperda. Sculptures along the second declivital interstriae were analysed in $116 \mathrm{~T}$. piniperda and $114 \mathrm{~T}$. destruens, using both callow (81) and mature adults (114) (Tables 1 and 2).

\section{(7) Setation of the costal vein}

Number, density and distribution of the setae occurring along the costal vein of the membranous wings were analysed for 116 $T$. piniperda and $114 \mathrm{~T}$. destruens, considering both wings of each specimen.

(8) Shape of aedeagus and eighth female sternite

The shape of aedeagus, spiculum and eighth female sternite are sometimes useful in scolytid identification (Fuchs, 1912; Butovitsch, 1929). However, in the genus Tomicus the eighth sternite of both male and female are very small and composed of two weakly sclerified pieces joined by an unsclerified membrane (Figs 2-3), which easily dissolves or breaks during the extraction procedure. In addition, the eighth sternite is hidden 


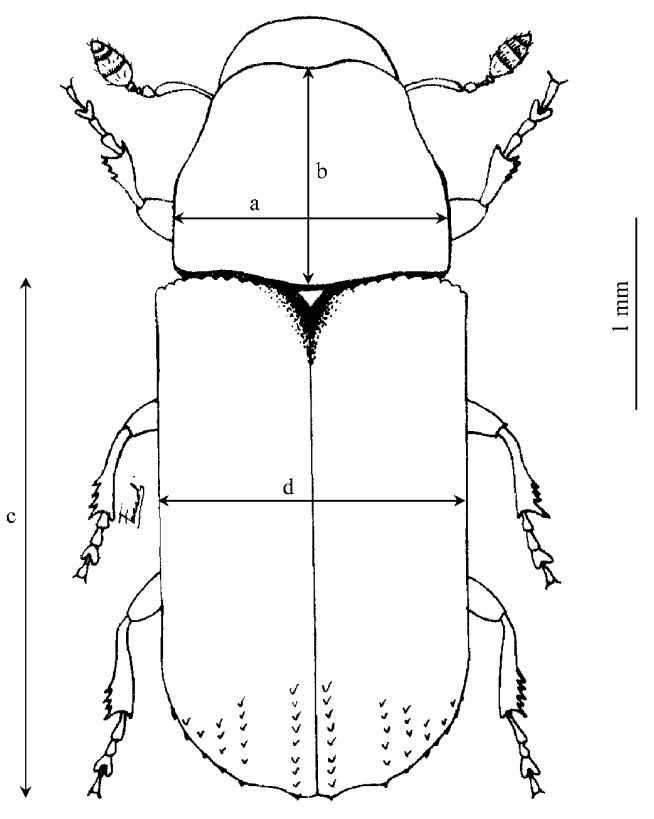

Fig. 4. Body measures taken in Tomicus destruens and $T$. piniperda: $\mathrm{a}$ - width of the posterior part of the pronotum; $\mathrm{b}$ length of the pronotum; $\mathrm{c}$ - length of the elytra; $d$ - width of the elytra.

by the eighth tergite (pygidium) both in males and females. For these reasons, beside the aedeagus and the spiculum, our investigations were focused on pygidium (eighth tergite) (Figs 10-11) and propygidium (seventh tergite) (Figs 12-13) of mature males and females of $59 \mathrm{~T}$. piniperda and $90 \mathrm{~T}$. destruens (Tables 1 and 2).

(9) Structure of the stridulatory device

Males of Tomicus produce sound by a stridulatory device made by a plectrum, two paired conical teeth located on the posterior margin of the propygidium, and a pars stridens occurring on the inner face of the elytra. As in North American species of the genus Ips, density and shape of pars stridens are useful for species identification (Lanier, 1970a, b), the structure of the stridulation device was investigated by S.E.M. in 298 elytra of
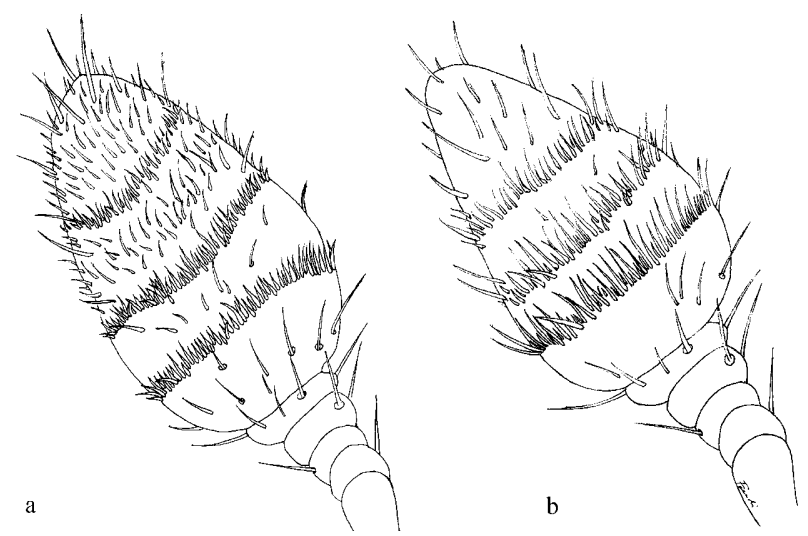

Fig. 5. Antennal clubs of Tomicus destruens (a) and $T$. piniperda (b). Note the different setation of the third segment and along the suture of the first segment.

$59 T$. piniperda and $90 T$. destruens. Only mature adults were used.

\section{(10) Body proportions}

The body proportions can vary among species as observed by Wollaston (1865), who described $T$. destruens a "little larger and thicker than $T$. piniperda". Lekander (1971) confirmed the description made by Wollaston (1865), measuring $44 T$. destruens from France and 44 T. piniperda from Sweden, but no values were reported in his paper. In this regard, total length and width of elytra and pronotum were recorded in $116 \mathrm{~T}$. piniperda and $114 T$. destruens (Tables 1 and 2). The measurements concerned the width of the posterior part of the pronotum (Fig. 4a), the length of the pronotum (Fig. 4b), the length of the elytra (Fig. 4c), and the width of elytra (Fig. 4d).

\section{Insect handling and sample preparation}

The analyses were carried out using a Wild ${ }^{\circledR}$ stereoscopic dissecting microscope $(50 \times)$ and a Wild $^{\circledR}$ microscope $(100 \times)$, except for the studies concerning density of pars stridens and elytral setation where a S.E.M. was used. The samples analysed by microscope (antennal clubs, membranous wings and genitalia) were prepared by leaving the insect in a $\mathrm{KOH}$ solution for 30 minutes at $80^{\circ} \mathrm{C}$; then, the body was dissected and the
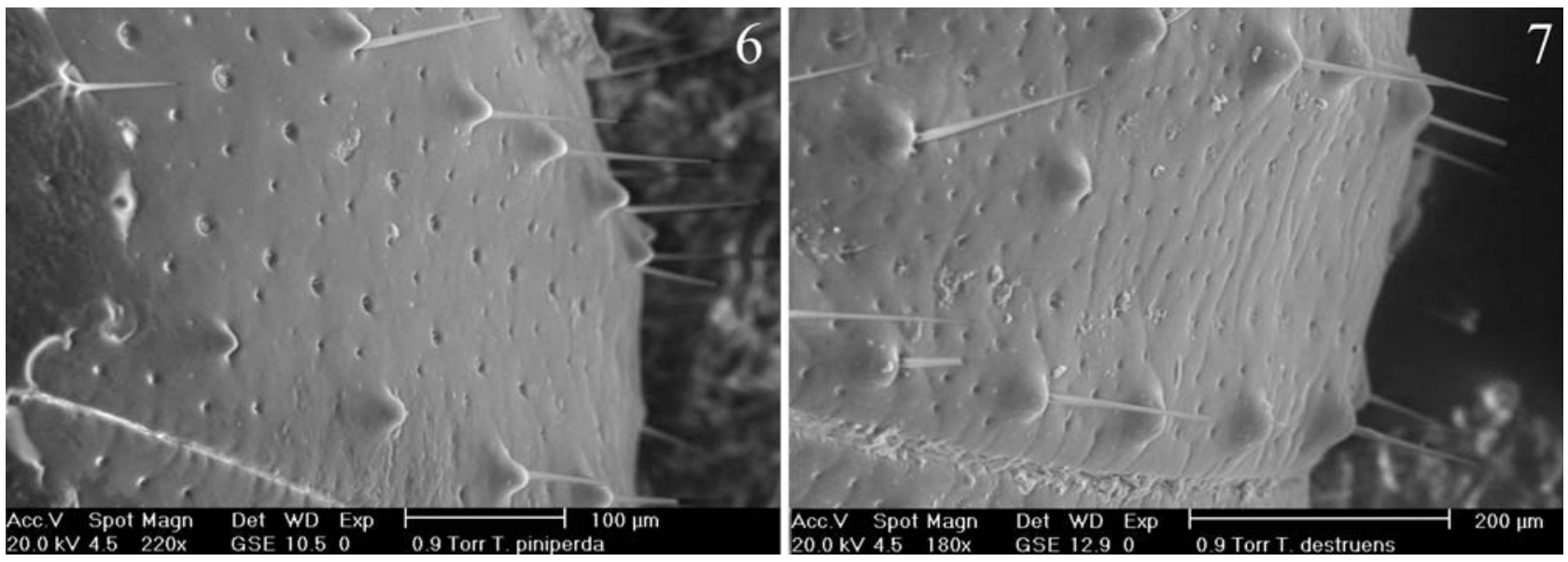

Figs 6-7. 6 - Punctures of the second interstriae along the declivity of the elytra of Tomicus piniperda. Note the uniseriate small punctures running between the two rows of the main punctures. The tegument is smooth, with no evident crenulation. $7-$ Punctures and transverse crenulation of the second interstriae along the declivity of the elytra of $T$. destruens. Note the small and deep punctures scattered between the two rows of the main punctures. 


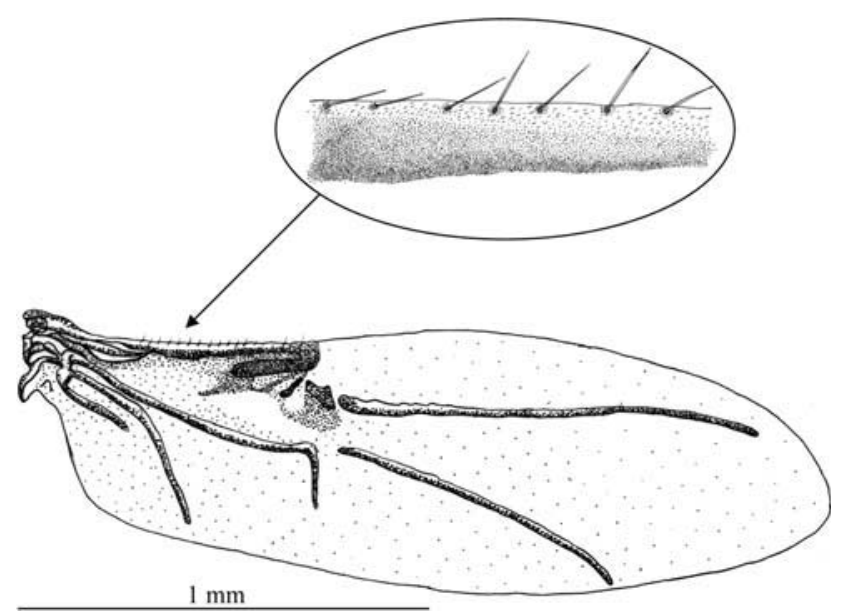

Fig. 8. Membranous wing of Tomicus destruens and magnification of setae occurring along the costal vein.

investigated samples were left for few seconds in ethanol $75 \%$, ethanol $90 \%$ and pure xylol successively. Finally, the samples were fixed on slides in Canada balsam.

\section{Statistical analysis}

Data were subjected to analysis of variance (ANOVA test) by the General Linear Model for randomised block designs (Zar, 1999) for determination of differences between the mean values.

Homogeneity of variance was tested using Cochran's test and, when necessary, data were $\log$-transformed $\left[X^{\prime}=\log (x+1)\right]$ or $\arcsin$-transformed $\left(\mathrm{X}^{\prime}=\arcsin \sqrt{\mathrm{P}_{\mathrm{x}}}\right)$ to obtain homogeneous variances. Where significant differences occurred, Tukey's honestly significant difference (HSD) multiple comparison test was
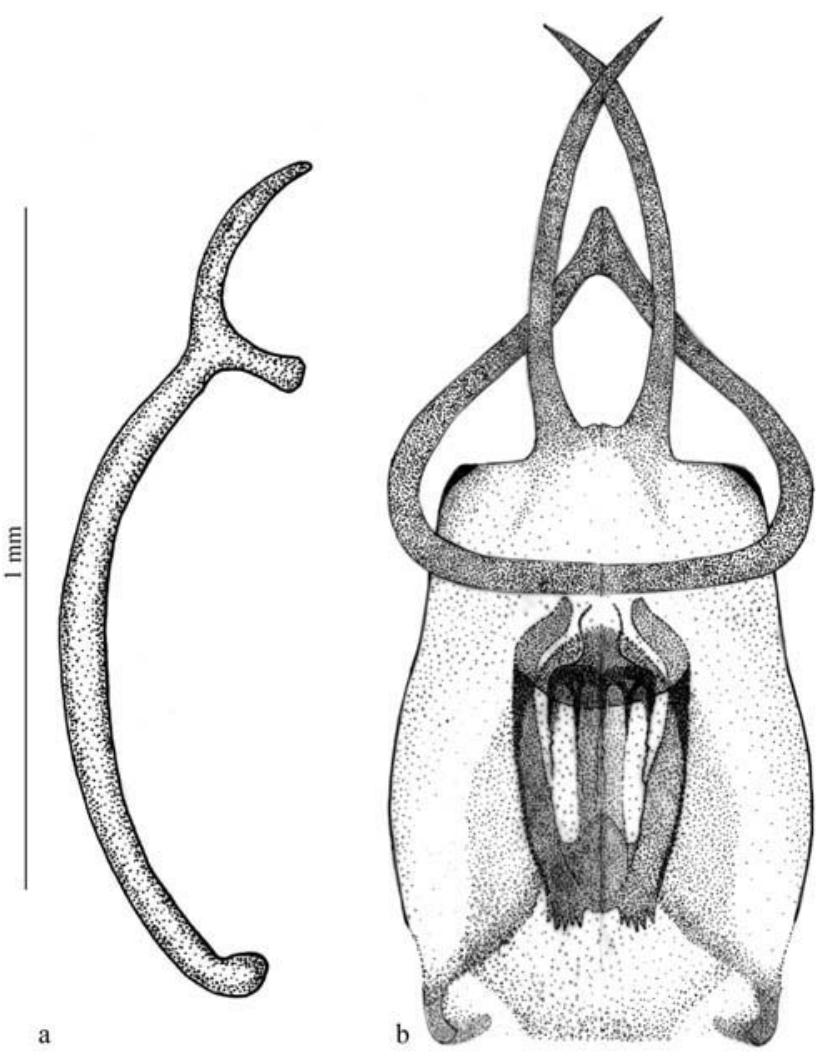

Fig. 9. Spiculum (a) and aedeagus (b) of Tomicus destruens.
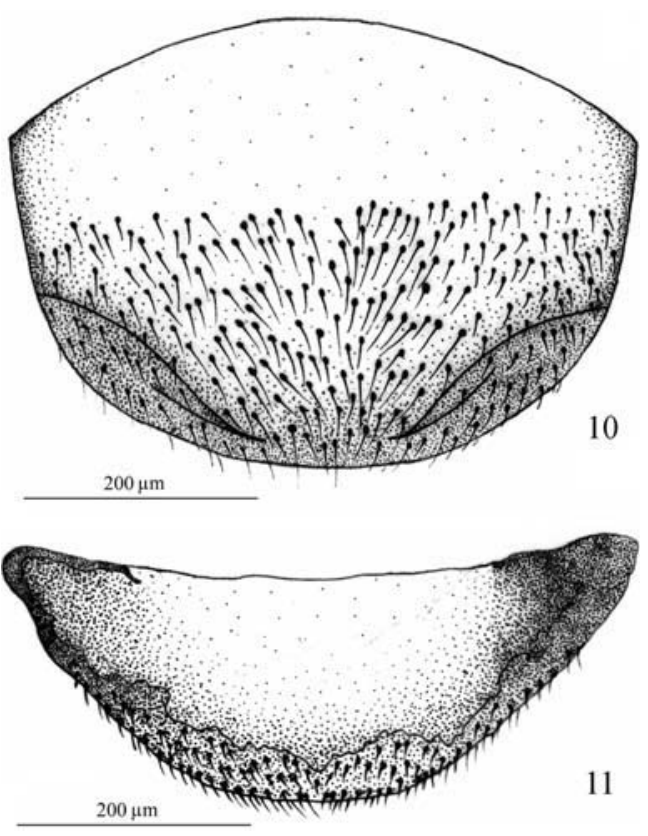

Figs 10-11. 10 - eighth male tergite (pygidium) of Tomicus destruens; 11 - eighth female tergite of $T$. destruens.

applied for mean separation (Zar, 1999). Data having a nonnormal distribution were subjected to chi-square $\left(\chi^{2}\right)$ analysis. Differences at 0.05 level of confidence were considered significant. Analyses were performed by the STATISTICA ${ }^{\circledR}$ per WINDOWS $^{\circledR}$ software.

\section{RESULTS AND DISCUSSION}

\section{(1) Colour of elytra}

Mature adults of the two species had different elytral colour (Table 3). In this respect, $T$. destruens always had elytra lighter and more reddish than the pronotum, whereas $T$. piniperda had elytra dark-brown or black with a colour similar to that of the pronotum. Therefore, besides to that previously reported (Wollaston, 1865; Reitter, 1913; Krausse, 1920), the comparison between elytral and pronotum colour is also useful for Tomicus identification. However, callow adults of both species have a similar homogeneous yellow colour, thus for young specimens other characters must be used for identification.

\section{(2) Colour of antennal club}

Overall, $97.5 \%$ of $T$. piniperda specimens had the antennal club browner than the funicle, whereas $96.2 \%$ of $T$. destruens had both antennal club and funicle pale (Table 3). In a few cases the character was not recognizable. The character was easily visible in both mature and callow adults, without statistical differences (Tables 5 and $6)$. The colour of the antennal clubs is one of the differentiating characters reported in the original description made by Wollaston in 1865 . Moreover, in a more recent key for identification of Palaearctic bark beetles, Pfeffer (1995) reported club colour as the only character useful for separation of these two Tomicus species. 

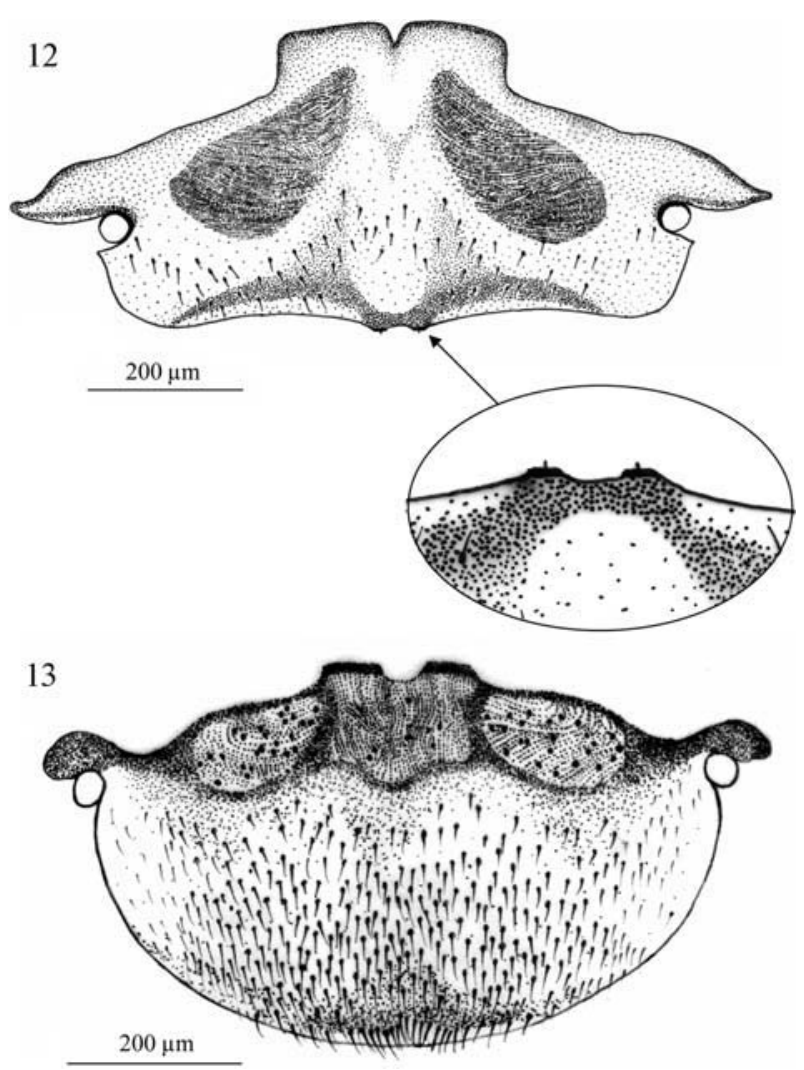

Figs 12-13: 12 - seventh male tergite (propygidium) of Tomicus destruens and magnification of the plectrum; 13 - seventh female tergite of $T$. destruens.

\section{(3) Setation of antennal club}

The distribution of setae occurring on the third antennal segment was denser in $T$. destruens than in $T$. piniperda (Table 3), especially in the upper part of the club (Fig. 5). Concerning $T$. piniperda, $69.9 \%$ of the specimens showed the character proposed by Kohlmayr et al. (2002), whereas in $27.8 \%$ of the adults the character was not visible. For $T$. destruens the character occurred in $82.3 \%$ of the specimens but was not identifiable in $13.9 \%$ of the adults. Finally, $6.3 \%$ of $T$. destruens were similar to $T$.

TABLE 3. Statistical analysis (test $\chi^{2}$ ) of non-normal data from the morphological comparison of Tomicus destruens and $T$. piniperda. Differences at 0.05 level of confidence were considered significant.

\begin{tabular}{lcccc}
\hline \multicolumn{1}{c}{ Character } & $D f$ effect & $D f$ error & $\chi^{2}$ value $P$ level \\
\hline Colour of elytra & 1 & 148 & 57.03 & 0.001 \\
Colour of antennal club & 1 & 217 & 131.24 & 0.001 \\
Setae of third club segment & 1 & 181 & 58.33 & 0.001 \\
Setae of first club suture & 1 & 181 & 73.87 & 0.001 \\
Punctures of declivity & 1 & 229 & 52.61 & 0.001 \\
Sculpture of declivity & 1 & 229 & 28.06 & 0.001 \\
Elytral length/width & 1 & 229 & 9.21 & 0.01 \\
Elytra/pronotum length & 1 & 229 & 6.99 & 0.01 \\
Elytral length/pronotum width & 1 & 229 & 8.84 & 0.01 \\
\hline
\end{tabular}

TABLE 4. Statistical analysis (ANOVA) of normal data from the morphological comparison of Tomicus destruens and $T$. piniperda. Differences at 0.05 level of confidence were considered significant.

\begin{tabular}{|c|c|c|c|c|}
\hline Character & \multicolumn{4}{|c|}{$D f$ effect $D f$ error $F$ value $P$ level } \\
\hline Number of setae on costal vein & 1 & 459 & 0.08 & 0.66 \\
\hline Density of setae on costal vein & 1 & 459 & 0.10 & 0.61 \\
\hline $\begin{array}{l}\text { Distance first-last setae on } \\
\text { costal vein }\end{array}$ & 1 & 459 & 0.18 & 0.57 \\
\hline Density of the pars stridens & 1 & 297 & 33.13 & 0.001 \\
\hline
\end{tabular}

piniperda. There were not statistical differences between callow and mature adults (Tables 5 and 6).

During the present study a new morphological difference was found. In $83.5 \%$ of $T$. piniperda the upper margin of the first antennal segment had two different types of setae, one short and one long (Fig. 5b), placed in a single row, whereas $86 \%$ of $T$. destruens had only short setae (Fig. 5a) (Table 3). The new character, which has higher accuracy $(83.5 \%$ of $T$. piniperda and $86 \%$ of $T$. destruens) than the character proposed by Kohlmayr et al. (2002) $\quad 69.9 \%$ of $T$. piniperda and $82.3 \%$ of $T$. destruens), occurred both in callow and mature adults (Tables 5 and 6).

\section{(4) Type and distribution of setae along the elytral interstriae}

This do not seem to be a good morphological character for Tomicus identification as no differences were found in the elytral setae of the two species, neither by stereoscope nor by SEM. The three types of setae (A, B and C) described by Kohlmayr et al. (2002) occurred on the elytra of both the species, with the setae of type $\mathrm{C}$ occurring only sporadically.

\section{(5) Distribution of punctures along the declivity}

According to Kerdelhué et al. (2002), the distribution of the punctures on the second interstriae along the declivity was different between species (Table 3). Tomicus piniperda had uniseriate, small and deep punctures occurring between the large and shallow punctures of the striae (Fig. 6). Tomicus destruens had similar punctures, but they were arranged in two or three irregular rows (Fig. 7). Wood also reported this difference in an unpublished key to Tomicus genus (pers. comm., 1999). Although the character is usually good for species separation, it did not occur in all specimens, and for both species it was more visible in mature compared with callow adults (Tables 5 and 6).

TABLE 5. Statistical analysis (test $\chi^{2}$ ) of non-normal data from the morphological comparison of mature and callow adults of Tomicus destruens. Differences at 0.05 level of confidence were considered significant.

\begin{tabular}{lcccc}
\hline \multicolumn{1}{c}{ Character } & $D f$ effect & $D f$ error & $\chi^{2}$ value & $P$ level \\
\hline Colour of antennal club & 1 & 105 & 0.02 & 0.34 \\
Setae of third club segment & 1 & 97 & 0.33 & 0.21 \\
Setae of first club suture & 1 & 97 & 0.09 & 0.48 \\
Punctures of declivity & 1 & 113 & 45.9 & 0.01 \\
\hline
\end{tabular}




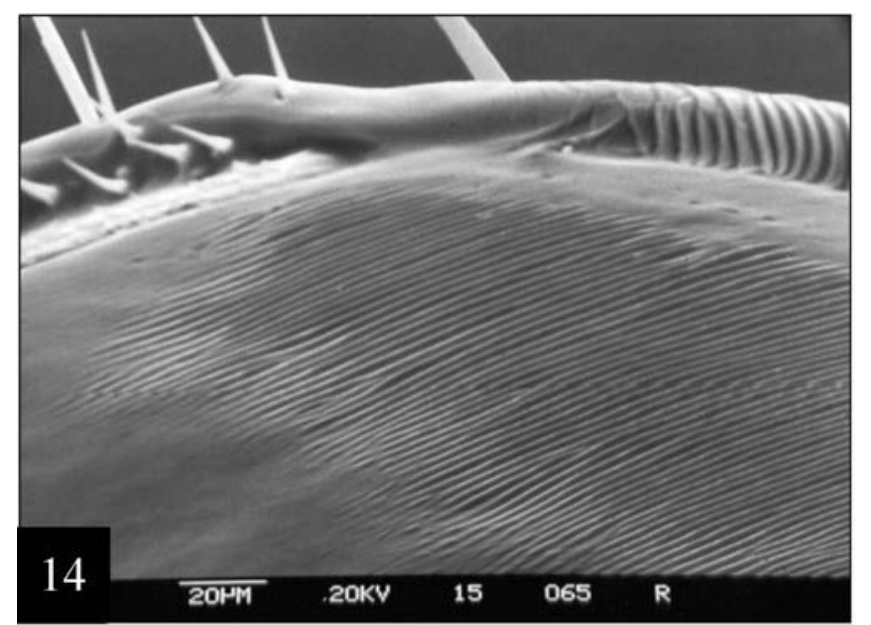

Fig. 14-15. 14 - Pars stridens of Tomicus destruens. 15 Pars stridens of Tomicus destruens (a) and T. piniperda (b), taken at the same magnification. See the different density of the striae.
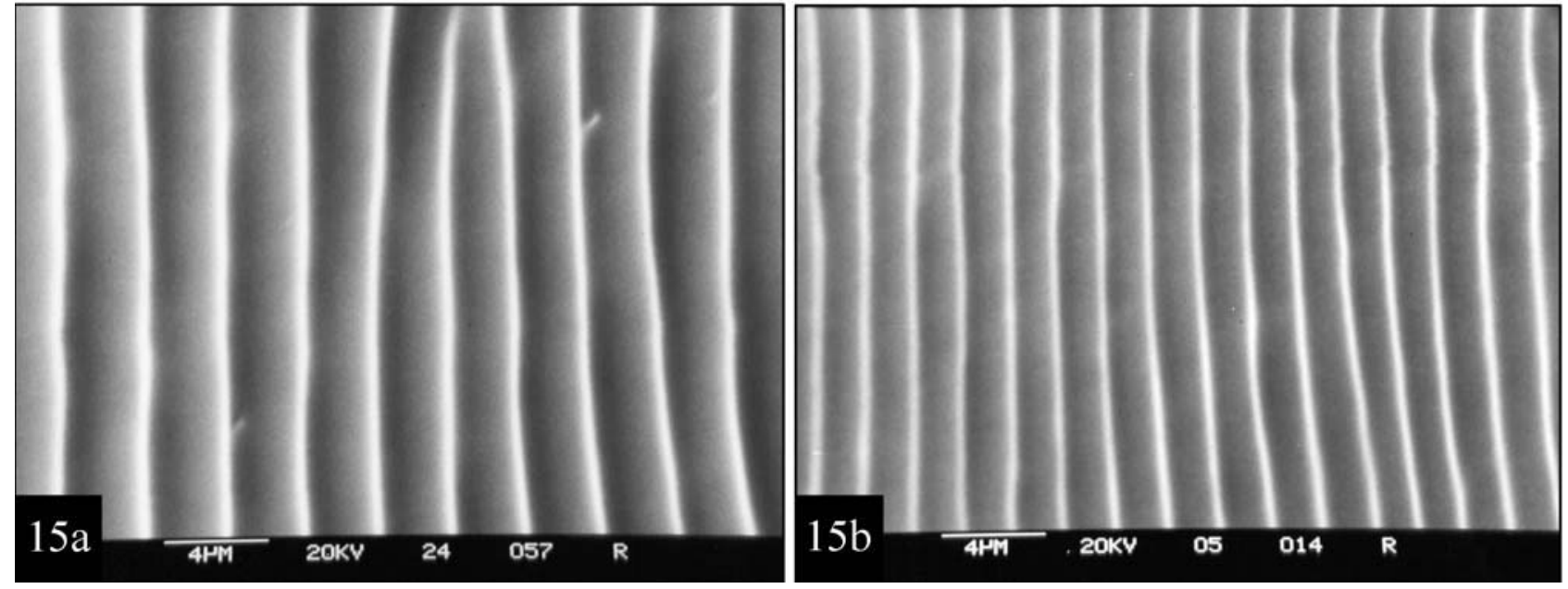

\section{(6) Sculpture of elytral declivity}

The declivity of both species was weakly, irregularly, transversely wrinkled, most easily seen on interstiae 2 where no setae occur (Figs 6-7), but in most $T$. destruens specimens the sculpture of the second declivital interstriae was more wrinkled than in T. piniperda (Table 3).

Our observations partially confirm the character proposed by Wollaston (1865), who described the elytral declivity of $T$. destruens as more "opaque and wrinkled" than in T. piniperda. Nevertheless, there were no relevant differences between species in the lustre of the elytral declivity, and the shining of the second interstria was similar in both species. The character was more visible in mature than in callow adults.

TABLE 6. Statistical analysis (test $\chi^{2}$ ) of non-normal data from the morphological comparison of mature and callow adults of Tomicus piniperda. Differences at 0.05 level of confidence were considered significant.

\begin{tabular}{lcccc}
\hline \multicolumn{1}{c}{ Character } & $D f$ effect & $D f$ error & $\chi^{2}$ value & $P$ level \\
\hline Colour of antennal club & 1 & 111 & 1.33 & 0.21 \\
Setae of third club segment & 1 & 83 & 0.06 & 0.64 \\
Setae of first club suture & 1 & 83 & 0.69 & 0.82 \\
Punctures of declivity & 1 & 115 & 69.3 & 0.001 \\
\hline
\end{tabular}

\section{(7) Setation of the costal vein}

The two species showed no statistical difference in both the number of setae, their density or the distance between first and last setae occurring along the costal vein of the membranous wings (Table 4, Fig. 8). Therefore, this character is not reliable for Tomicus identification.

\section{(8) Shape of aedeagus and tergites}

The genitalia, which can provide important morphological characters (Fuchs, 1912; Butovitsch, 1929), were similar between the two species. Males of T. piniperda and $T$. destruens had aedeagus and spiculum similar in shape and size (Fig. 9). Likewise, pygidium (eighth tergite) (Figs 10-11) and propygidium (seventh tergite) (Figs 12-13) were similar between species, and different between sexes. None of the investigated segments shows morphological differences visible by stereoscope or microscope.

\section{(9) Structure of the stridulatory device}

Tomicus males are able to produce sound by a stridulatory device constituted by two conical bristles (plectrum) situated on the central part of the posterior margin of the propygidium (Fig. 12). The plectrum scrapes against tegumental striae (pars stridens), which are situated on the adjacent inner surface of the elytra (Fig. 14), producing sound. Females have a small pars stridens but no 
Density of the pars stridens

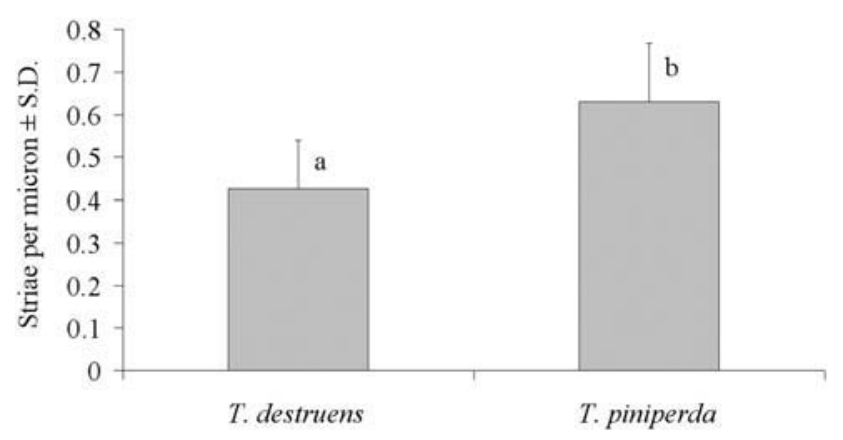

Fig. 16. Density of the pars stridens of Tomicus destruens and T. piniperda (Different letters indicate statistical differences between species).

plectrum, so they are unable to produce sound. The pars stridens of Tomicus males covers a large area along the inner and postero-medial part of the elytra (close to the elytral suture), and no differences were found between species in either shape or size (Fig. 14). However, the density of striae along the pars stridens was higher in $T$. piniperda than in T. destruens (Table 4, Fig. 15). The pars stridens of $T$. piniperda had in average 0.63 striae per micron, whereas only 0.42 occurred in $T$. destruens (Fig. 16). No differences were found between species in shape, size and position of the plectrum (Fig. 12). In many bark beetles, stridulation is known to be important for aggregation and mating (Rudinsky et al., 1973; Rudinsky \& Michael, 1973; Rudinsky \& Ryker, 1976; Rudinsky \& Vallo, 1979). Different densities of pars stridens could determine different sound emissions, which can lead to reproductive isolation among closely related species, as $T$. destruens and T. piniperda.

\section{(10) Body proportions}

The ratio between length and width of the elytra was different between species, higher in $T$. piniperda $(>1.7)$ than in $T$. destruens $(<1.7)$ (Table 3$)$. Also, the ratio between elytra and pronotum length was higher in $T$. piniperda $(>2.35)$ than $T$. destruens $(<2.35)$ (Table 3$)$. Finally, the ratio between elytral length and pronotum width was higher in $T$. piniperda $(>1.9)$ than $T$. destruens $(<1.9)$ (Table 3). Lekander (1971) supported the general observations made by Wollaston (1865) concerning the different size and shape of the two species, describing $T$. destruens as on average a little "larger and wider" than $T$. piniperda. Our measurements give similar results with $T$. piniperda having in general a slimmer silhouette than $T$. destruens. Finally, we found no significant differences between species in shape and proportions of the pronotum, although Lekander (1971) described the form of the pronotum as "more pear-like in the piniperda than in destruens in which species it is broadest at the base, tapering gradually forwards, and therefore barely pearshaped".

\section{CONCLUSIONS}

One aim of systematic research is to find clear morphological characters useful for species separation. Nevertheless, in many cases the available characters are few and weak. The acceptance of $T$. destruens as a different species from $T$. piniperda has been relatively recent due to the absence of clear diagnostic differences between the two species. In addition, many descriptions were not very useful for taxonomic purposes, as they did not provide figures concerning the differentiating characters (Wollaston, 1865; Reitter, 1913; Krausse, 1920). Although Lekander (1971) reported clear drawings of the larval epipharyngeal setae, his sketches of the adults are not very useful. Only recent genetic analyses have confirmed the validity of $T$. destruens as a separate species (Gallego \& Galian, 2001; Kerdelhuè et al., 2002; Kohlmayr et al., 2002; Faccoli et al., 2005). However, the present morphological investigation allowed for the discovery or confirmation of eight characters that differentiate $T$. destruens and $T$. piniperda. They include elytra colour, antennal club colour, density of antennal club setae, setation of the first antennal club suture, punctuation of the second declivital interstriae, structure of stridulatory device, body proportions, and sculpture on the elytral declivity. On the other hand, three of the eleven investigated characters, such as the type of setae of the elytral interstriae, density of setae along the costal vein, and the shape and size of genitalia, were not useful in separating the two species. All morphological differences reported in the literature are good for Tomicus separation, except the setation of the elytral interstriae proposed by Kohlmayr et al. (2002), which probably needs a more detailed analysis. In addition, the differences among setae are visible only by SEM. Concerning the original observations carried out in the present paper, the density of the pars stridens, the setation of the first suture of the antennal clubs, and the body proportions are new characters useful for separation of $T$. piniperda and $T$. destruens. Finally, callow adults of $T$. destruens and $T$. piniperda can be easily separated using all the proposed characters, except the colour of the elytra. However, the punctures occurring on the declivital interstriae and the sculpture of the elytral declivity are more difficult to see in callow than in mature adults.

Data from the investigated populations (Table 1 and 2) and from the literature indicated $T$. destruens as a thermophile species living in Mediterranean and Atlantic regions (Fig. 1), which include western localities such as Madeira (Wollaston, 1865; Lekander, 1971), Spain (Lekander, 1971; Kohlmayr et al., 2002) and Mallorca (Lekander, 1971), central Mediterranean including North Africa (Algeria), Italian and Greek coasts (Fig. 1), Sardinia and Tuscany archipelagos (Faccoli \& Cecchi, 2003), and finally eastern regions as Turkey, Cyprus and Israel (Lekander, 1971). Tomicus piniperda has a larger Eurasian distribution. However, in southern Europe it is possible to find overlapping populations of the two species, especially in southern France, northern Spain, Portugal, and the Balkan peninsula (Kerdelhuè et al., 2002; Gallego et al., 2004). In this respect, it would be interesting to 
continue the preliminary experiments of Carle (1974) concerning the interfecundity of the two species. Similar shape and size of genitalia could allow mating between $T$. destruens and $T$. piniperda, although different densities of the pars stridens suggest different sound emissions, which may play a major role in avoiding mating.

\section{Key for $T$. piniperda and $T$. destruens separation}

Because some of the described characters do not occur in all specimens, the best way for species separation is through a careful analysis of the specimens, using a combination of all characters reported in the following key:

1 Mature colour of elytra dark brown, colour of antennal club darker than antennal funicle, third antennal segment with few isolated setae (Fig. 5b), upper margin of the first antennal club segment with both short and long setae (Fig. $5 b)$, second interstriae of the declivity smooth, with uniseriate, small and deep punctures (Fig. 6), length/width of elytra $>1.7$, elytra/pronotum length $>2.35$, elytral length/pronotum width $>1.9$. Distribution: Eurasia, including Japan; introduced into N. America. Host-trees: Mainly on continental pine species and Pinus pinaster. In N America on Scots pine (P. sylvestris L.), jack pine ( $P$. banksiana Lamb.), red pine (P. resinosa Aiton) and eastern white pine (P. strobus $\mathrm{L}$.). . . ................... T. piniperda (Linnaeus, 1758) - Mature colour of elytra reddish, antennal club of the same colour of the antennal funicle, third antennal segment with abundant vestiture of many setae (Fig. 5a), upper margin of the first antennal club segment with only short and regular setae (Fig. 5a), second interstriae of the declivity transversely wrinkled, with 2 or 3 rows of punctures (Fig. 7), length/width of elytra $<1.7$, elytra/pronotum length $<2.35$, elytral length/pronotum width $<1.9$. Distribution: Mediterranean regions of N. Africa, S Europe, and SW Asia. Hosttrees: Mediterranean pine species such as Pinus pinaster, $P$. pinea, $P$. canariensis, $P$. brutia and $P$. halepensis. . . . . . . T. destruens (Wollaston, 1865)

ACKNOWLEDGEMENTS. The author is very grateful to $\mathrm{R}$. Haack, M. Knížek and L. Kirkendall who reviewed the manuscript and provided numerous suggestions for its improvement. Many thanks to all the people listed in tables 1 and 2 for their help in collecting and sending Tomicus specimens. Special thanks to C. Stauffer for providing part of his insect collection.

\section{REFERENCES}

Balachowsky A. 1949: Coléoptères Scolytides. Faune de France 50. Libraire de la Facultè des Sciences, Paris, 320 pp.

Butovitsch V. 1929: Studien über die Morphologie und Systematik der paläarktischen Splintkäfer. Stett. Entomol. Zeit. 90: $1-80$.

CARle P. 1974: Mise en évidence d'une attraction secondarie d'origine sexuelle chez Blastophagus destruens Woll. (Col. Scolytidae). Ann. Zool. Écol. Anim. 6: 539-550.

CARLE P. 1975 : Problèmes posés par les ravageurs xylophages des conifères en forêt méditerranéenne. Rev. For. Fr. 27: 283-296.

Chararas C. 1962: Étude Biologique des Scolytides des Conifêres. Enc. Ent. 37, Lechevalier, Paris, 555 pp.

DAJOz R. 2000: Insects and Forest: The Role and Diversity of Insects in the Forest Environment. Techniques and Documentations Editions, Paris, 668 pp.

EgGERs H. 1929: Zur Synonymie der Borkenkäfer (Ipidae, Col.). Wien. Entomol. Zeit. 46: 41-55.
ЕichноғF W.J. 1881: Die Europäischen Borkenkäfer. J. Springer, Berlin, $315 \mathrm{pp}$.

Escherich K. 1923: Forstinsekten Mitteleuropas. Band II. Paul Parey, Berlin, 663 pp.

Faccoli M., Piscedda A., Salvato P., Simonato M., Masutti L. \& Battisti A. 2005: Phylogeography of the pine shoot beetles Tomicus destruens and T. piniperda (Coleoptera: Scolytidae) in Italy. Ann. Forest Sci. 62: 361-368.

FACCOLI M. \& CECCHI B. 2003: Contributo alla conoscenza dell'Ipidofauna dell'arcipelago toscano (Coleoptera Scolytidae). Redia 86: 133-138.

Ferreira M.C. \& Ferreira G.W.S. 1986: Pragas do pinheiro bravo em Portugal - Escolitideos. Bol. Agric. 36: 1-4.

Fuchs G. 1912: Morphologische Studien über Borkenkäfer - II. Die europäischen Hylesinen. Reinhardt, München, 53 pp.

Gallego D. \& Galí́n J. 2001: The internal transcribed spacers (ITS1 and ITS2) of the rDNA differentiate the bark beetle forest pests Tomicus destruens and T. piniperda. Ins. Mol. Biol. 10: 415-420.

Gallego D., Cánovas F., Esteve M.A. \& Galián J. 2004: Descriptive biogeography of Tomicus (Coleoptera: Scolytidae) species in Spain. J. Biogeog. 31: 2011-2024.

Gil L. \& Pajeras J.A. 1986: Los Escolitídos de las Coniferas en la Península Ibérica. Publicaciones del Ministerio de Agricultura, Pesca y Alimentación - Secretaría General Técnica, Madrid, 194 pp.

HAack R.A. \& Kucera D. 1993: New Introduction - Common Pine Shoot Beetle, Tomicus piniperda (L.). USDA Forest Service, Northeastern Area, Pest Alert NA-TP-05-93.

Haack R.A., Poland T.M., Patrice T.R. \& Gennrich M.A. 2000: Range expansion of Tomicus piniperda since 1992 and notes on other new exotics. Michigan Entomol. Soc. 45: 9-10.

HAACK R.A. \& POLAND T.M. 2001. Evolving management strategies for a recently discovered exotic forest pest: the pine shoot beetle, Tomicus piniperda (Coleoptera). Biol. Invas. 3: 307-322.

Kerdelhuè C., Roux-Morabito G., Forichon J., Chambon J.-M., Robert A. \& Lieutier F. 2002: Population genetic structure of Tomicus piniperda (Curculionidae: Scolytinae) on different pine species and validation of T. destruens (Woll.). Mol. Ecol. 11: 483-494.

Kohlmayr B., Riegler M., Wegensteiner R. \& Stauffer C. 2002: Morphological and genetic identification of the three pine pests of the genus Tomicus (Coleoptera, Scolytidae) in Europe. Agr. For. Entomol. 4: 151-157.

Krausse A.M. 1920: Die Arten, Rassen und Varietäten des grossen Waldgärten (genus Blastophagus Eich.). Z. Forst. Jagdw. 52: 169-178.

LÃNGSTRÖM B. \& Hellqvist C. 1991: Spatial distribution and crown damage and growth losses caused by recurrent attacks of pine shoot beetles in pine stands surrounding a pulp mill in southern Sweden. J. Appl. Entomol. 110: 261-269.

LANIER G.N. 1970a: Biosystematics of North American Ips (Coleoptera: Scolytidae). Hopping's group IX. Can. Entomol. 102: 1139-1163.

LANIER G.N. 1970b: Biosystematics of North American Ips (Coleoptera: Scolytidae). Hopping's group III. Can. Entomol. 102: 1404-1423.

LEKANDER B. 1971: On Blastophagus destruens Woll. and a description of its larva (Col. Scolytidae). Entomol. Tidskrift 92: 271-276.

Masutti L. 1969: Pinete dei litorali e Blastophagus piniperda L. - Una difficile convivenza. Monti e Boschi 3: 15-27.

Pfeffer A. 1995: Zentral- und westpaläarktische Borken- und Kernkäfer (Coleoptera: Scolytidae, Platypodidae). Pro Entomologia, c/o Naturhistorisches Museum Basel, 310 pp. 
Postner M. 1974: Scolytidae Borkenkäfer. In Schwenke W. (ed.): Die Forstschädlinge Europas. Bd. 2, Käfer. Paul Parey, Hamburg und Berlin, pp. 334-487.

ReItTer E. 1913: Bestimmungstabelle der Borkenkäfer (Scolytidae) aus Europa und den angrenzenden Ländern. Wien. Entomol. Zeit. 32: 1-116.

RUdinSKY J.A. \& Michael R.R. 1973: Sound production in Scolytidae: Stridulation by female Dendroctonus beetles. J. Insect Physiol. 19: 689-705.

RUDINSKY J.A. \& RYKeR L.C. 1976: Sound production in Scolytidae: rivalry and premating stridulation of male Douglas-fir beetle. J. Insect Physiol. 22: 997-1003.

Rudinsky J.A. \& VAllo V. 1979: The ash bark beetles Leperisinus fraxini and Hylesinus oleiperda: stridulatory organs, acoustic signals, and pheromone production. Z. Ang. Entomol. 87: 417-429.

Rudinsky J.A., Morgan M.E., Libbey L.M. \& Michael R.R. 1973: Sound production in Scolytidae: 3-methyl-2cyclohexen-1-one released by the female Douglas-fir beetle in response to male sonic signal. Environ. Entomol. 2: 505-509.

Russo G. 1940: Il blastofago del pino (Blastophagus (Myelophilus) piniperda L. var. rubripennis Reitter). R. Lab. Entomol. Agr. Fac. Agr. Portici 19: 1-13.

Russo G. 1946: Scolitidi del Pino del litorale toscano. Boll. Ist. Entomol. "G. Grandi" Univ. Bologna 15: 297-314.

SchedL K.E. 1932: Scolytidae, Platypodidae. In Winkler A. (ed.): Catalogus Coleopterorum Regionis Palaearcticae. Wien, pp. 1632-1647.
SchedL K.E. 1946: Bestimmungstabellen der palaearktischen Borkenkäfer, II - Die Gattung Blastophagus Eichh. Zentr. Ges. Entomol. 1: 50-58.

Triggiani O. 1983: Sensibilità del Tomicus (Blastophagus) piniperda L., (Col., Scolytidae) ai nematodi della famiglia Steinernematidae e Heterorhabditidae. Entomologica 18: 215-223.

Triggiani O. 1984: Tomicus (Blastophagus) piniperda (Coleoptera, Scolytidae, Hylesininae): biologia, danni e controllo nel litorale ionico. Entomologica 19: 5-21.

Wollaston T.V. 1865: Coleoptera Atlantidum, Being an Enumeration of the Coleopterous Insects of Madeiran, Salvages and Canaries. Voorst, London, $526 \mathrm{pp}$.

Wood S.L. \& Bright D.E. 1992: A Catalogue of Scolytidae and Platypodidae (Coleoptera). Part 2: Taxonomic Index. Great Basin Naturalist Memoirs 13. Brigham Young Univ., Provo, Utah, $1553 \mathrm{pp}$.

YE H. 1991: On the bionomy of Tomicus piniperda (L.) (Col., Scolytidae) in the Kumming region of China. J. Appl. Entomol. 117: 190-194.

Ye H. \& Lieutier F. 1997: Shoot aggregation by Tomicus piniperda (L.) (Col., Scolytidae) in Yunnan, Southwestern China. Ann. For. Sci. 54: 635-641.

ZAR J.H. 1999: Biostatistical Analysis. Prentice Hall Press, Upper Saddle, NJ, 660 pp.

Received April 17, 2005; revised and accepted September 23, 2005 